\title{
The Cultivation Mode Exploration of Extracurricular "4+4+4" Professional Interests on the Basis of WeChat Platform---Taking the Example of the Specialty of Editing and Publishing
}

\author{
Liya Yao \\ School of Culture and Media, Jilin Engineering Normal University, Changchun, 130052, China \\ 415356818@qq.com
}

Keywords: WeChat; Extracurricular; Professional interests; “4+4+4” mode; Editing and publishing

\begin{abstract}
According to present conditions of students majoring in Editing and Publishing with common issues of low professional interests, based on the result of empirical investigation, it constructs cultivating the extracurricular supplementary teaching platforms on the basis of WeChat's " $4+4+4$ " professional interests.
\end{abstract}

\section{Introduction}

Professional interests refer to the positive psychological tendency presented when a person wants to know, touch and master some occupation. it has been an important reference for occupational choice [1]. Presently, students majoring in Editing and Publishing have had common issues of low professional interests, which are mainly shown as follows: high absence rate in major courses, poor efficiency of attending the courses, low passion in participating professional practice. Thus, it won't do well for other professional knowledge and learning of skills. However, cultivation of students' professional interests in professional teaching of Editing and Publishing hasn't been drawn enough attention from many aspects. Meanwhile, it is almost lost for the students to learn theoretical courses of professional interest cultivation and have the practice links.

As shown in the investigation on 2500 university students in 208 universities from 28 provinces (cities, districts), by the end of May, 2014,84.7\% of the university students have used WeChat social platforms and $32.8 \%$ of the students have acquired professional information by WeChat [2]. Students' high adhesiveness of WeChat platform and psychological trust have provided the inspiration on professional teaching of Editing and Publishing, which is how to insert the application process of students' WeChat to teaching contents of professional interests cultivation and develop extracurricular cultivation mode of professional interests based on WeChat platform. Therefore, it realizes the purpose that it won't occupy time of professional classes and it will improve students' professional interests.

The " $4+4+4$ " mode (Fig 1.) in the thesis is the professional interests mode of "four sections+ four bodies four platforms", which is based on the investigation of students' professional interests in major of Editing and Publishing in Jilin Engineering Normal University. Relying on WeChat, it carried out extracurricular supporting teaching platform in some students and courses. Simply speaking, according to students' characteristics of professional interests in different periods in university, it respectively establishes preliminary platform of friend circles of freshers and seniors, core platforms of the sophomores and professional teachers' WeChat subscription numbers, professional platforms of discussion team of the juniors and experts, terminal platforms of the seniors and the media service accounts. Meanwhile, extracurricular teaching materials for improving students' professional interests are pushed by WeChat platform throughout extracurricular supporting teaching for four university years, which will help students realize the aim of cultivating their professional interests. 


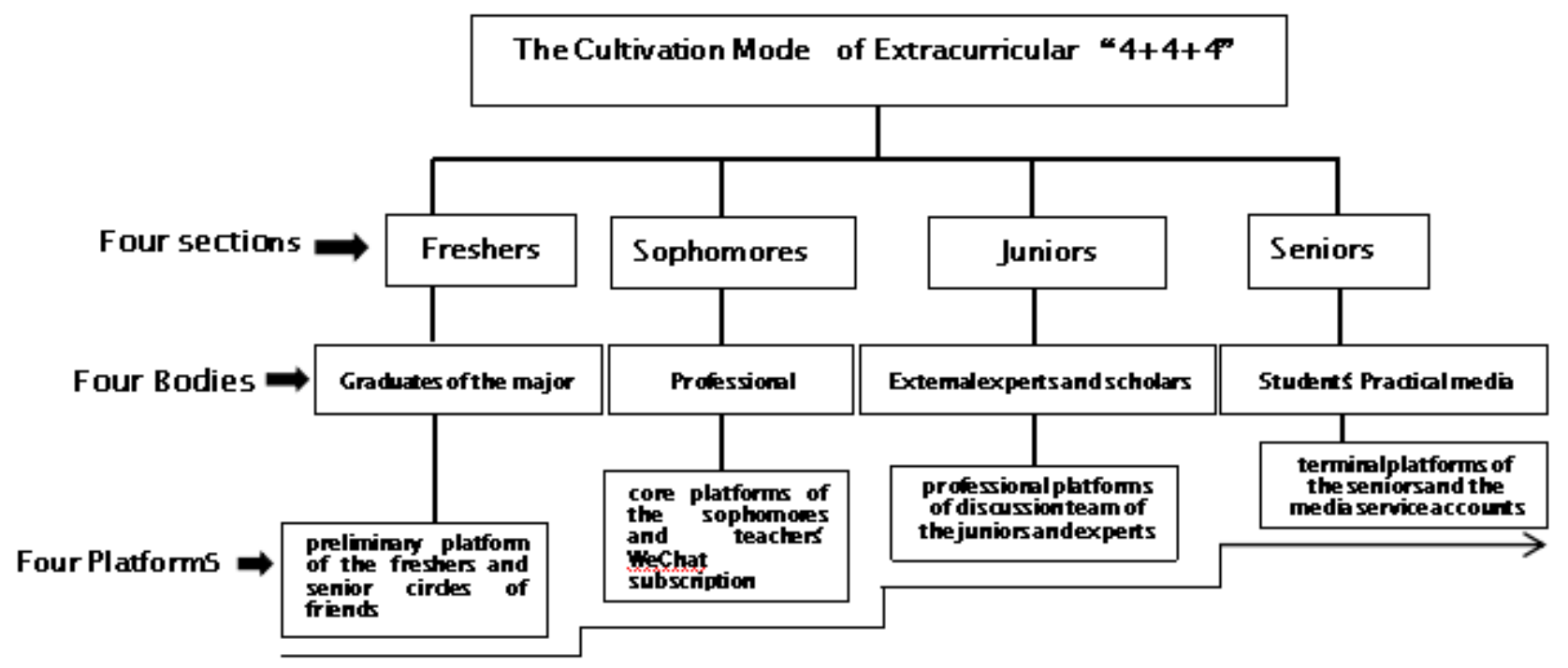

Figure 1.

\section{Reasonable Analyses on Constructing Cultivation Mode Based on Wechat Platforms}

The construction of WeChat teaching platform is in line with cognitional rule of university students. WeChat is a free app of instant communication based on smart terminal released by Tencent on January 21, 2011. As survey shown, at present, $84.7 \%$ of university students use WeChat. Meanwhile, $42.2 \%$ of them have used WeChat for more than a year, $63.7 \%$ of them have used WeChat for an hour every day and $32.8 \%$ of them have used WeChat to learn professional information [3]. University students' closeness and trust of WeChat make it have the psychological basis and practical basis of teaching in university.

It meets technical demands of talent cultivation of Editing and Publishing to construct WeChat teaching platform. Newspapermen are "early follow-ups" in application of new media [4]. The dependability of position and IT makes new media become working contents and methods of newspapermen. In talent cultivation of Editing and Publishing, it introduces WeChat to teaching. On the one hand, as one of teaching method, WeChat can improve students' professional interests; on the other hand, as teaching contents, the research of WeChat will accelerate students to research on new technology, which can be considered as "killing two birds with a stone."

It is the requirement for expanding classroom teaching of Editing and Publishing to construct WeChat teaching platform. The tight total periods and imbalance proportion of theory and practical periods have been common issues for course planning of Editing and Publishing in various universities. The WeChat platform of the " $4+4+4$ " mode is completely implemented out of the class. Without occupying the periods in class, it can be operated conveniently and have low cost.

\section{Reasonable Analysis on "Four Sections" Design}

In the mode of " $4+4+4$ ", the "Four Sections" mean the cultivation on students' professional interests should be implemented according to the unit of a grade. Respectively, it establishes four-level cultivation platform of grade 1,2, 3 and 4, cultivating professional interests in the total of four years and realizing the layering cultivation in the whole process.

Such design is based on the characteristics of professional interests of students majoring in Editing and Publishing. As the investigation shown, professional interests of students in our major have been shown with clear characteristics with the change of grades. Meanwhile, professional interests of fresher's rank the first among the four grades. As for sophomores, their professional interests are shown with sudden decreasing and ranked at the lowest position. The juniors begin to improve their professional interests and for the seniors, they keep improving their interests and maintain the level of fresher's. Objectively making analyses on the result, the reason why the 
fresher's have the most highly interest is because students lack reasonable knowledge of their major, conditions of they are engaged in. When students in grade two, they have got some knowledge of their major. In addition, with the increase of difficulty in professional knowledge and the amount of classes, students may feel it hard to adapt academic studies and it is reasonable for them to have low interests in their major. In grade three, with the increasing difficulty of professional knowledge, students have more reasonable thinking and their professional interests also begin to increase. In Grade four, students almost form their professional knowledge system and their professional interests will be kept stably at a comparatively high level.

The design of Four-section professional cultivation platform follows the above characteristics and agrees with different cultivation goals: students of Grade one focus on professional interests and students of Grade two begin to strengthen their professional interests. Then, students of Grade three have increased their professional interests and students of Grade four have had stable professional interests. In this way, it can basically cover professional interests in the whole process of four-year University.

\section{Reasonable Analysis on "Four Bodies” Design}

Integrated into platform supervisor and content publisher, the platform body is the key to success of "4+4+4" mode [5]. With the instruction of platform cultivation goal at different levels and combining students' characteristics of different grades, we have developed the idea of determining excellent graduates (seniors) as the platform body of grade one, professional teachers as the platform body of grade two, external experts as the platform body of grade three and the media as the platform body of grade four.

Taking excellent graduates dealing with news report as the platform body of grade one, we just consider they have common understandings with freshers because they have similar ages, experiences and beliefs, which will attract the freshers and keep the goal of students' professional interests. Taking professional teachers as the platform body of grade two, we just consider students have more professional assignments and professional interest cultivation should be synchronously implemented with professional teaching. Meanwhile, it is good for operation of platforms and make the synchronous implementation of in-class professional teaching and extracurricular professional interests cultivation. Therefore, it will realize the goal of strengthening students' professional interests with the presupposition of accomplishing teaching assignments [6]. As for the students of Grade three, they have improved their professional knowledge and skills greatly and have profound and reasonable knowledge of their specialty. We instruct students to have reasonable thinking in their professions by choosing external experts with more experiences in their field as platform body, which may improve students' professional interests. The seniors take practical media as platform body just because many of the students have begun to practice in media and they have more opportunities to understand the industry of media, which will help them adjust their professional interest and keep professional interest stable.

\section{Operational Mode of "Four Platforms"}

The construction of the preliminary cultivation platform of freshers and senior friends circle is simple and easy. Students can participate in it by applying and enjoy the contents of friend circles. On the platform, students graduated from the major and engaged in news report will share their experiences of starting to enter the occupation from anywhere at any time. From the front line of the position, these people have real and lively experiences, which will easily arouse students' professional interests and lay a good foundation of professional interests for sophomores.

The core platform of the sophomores and professional teachers' WeChat subscription number is mainly adopted three functions of public platform of subscription numbers which include timely communication, message pushing and materials management [7]. After applying for subscription numbers, the professional teachers implement the pushing of extracurricular teaching materials of professional interest cultivation once a day. The pushing materials should agree with two standards: 
firstly, it should present in-class language points and secondly, the characters, pictures, videos and sound should be reasonably combined. From students' participation, it can be seen that the subscription platform has improved students' academic passion in a very short time and deepen the understanding of knowledge.

The professional platform of discussion team of the juniors and experts is fully presented the principles of "help" and "share" of WeChat network transmission [8]. As for professional knowledge, ability, quality and academic vision, the juniors are better than freshers and sophomores and they have had independent thinking. On discussion platform, from enterprises, there are many yellow hands entering the periods of occupation reflections. With career experiences accumulated for many years, they change the experiences to get reasonable knowledge by analyzing and thinking. Sharing such knowledge with students on the platform, they will be aroused professional thinking and deepening students' professional understandings. Which will stimulate students to seek "help" from experts on the platform [9].

The terminal platform of the seniors and the media service accounts is also a kind of WeChat public platforms and it also has the function of pushing messages. Students in Grade four are generally in the stage of practice and have more opportunities of contacting the media. Therefore, their professional interests can be tested in real working conditions and positions. On WeChat platform, the body of practical media, considering themselves, the media will provide students with characters, pictures, videos, sounds, which have special features of the enterprises and overall features of traditional industries every month. In the process of interaction with media, the students can match their professional interests to real positions. Therefore, they can adjust their professional interests according to the result of matching and eventually finish the stable professional interest cultivation.

\section{Conclusion}

As a kind of spiritual cultivation, professional interest cultivation is a long process [10] . Considering the present condition that the students of the specialty have low professional interest and combining the characteristics of highly frequent application in students, the " $4+4+4$ "mode conducts the exploration of extracurricular supplementary teaching mode with the presupposition of failing to realize in-class cultivation in a short time. With the implementation of the mode for half a year, professional interests of students and their learning initiatives have improved a lot. In the thesis, it hopes to make more peers pay the attention on professional interest cultivation and participate in the discussion. Moreover, it hopes to provide some ideas for exploring the cultivation way of professional interests and constructing cultivation mode of professional interests through teaching practice.

\section{Acknowledgements}

This is the phased achievements of Jilin Youth Development Research Project of 2016 (number: 2016 jqy - 20) and the13th Five Plan Project of Jilin Education and Science Office of 2016, that is, Collaboration between Universities and Businesses in Innovative and Entrepreneurial Talent Training Curriculum Research—Taking the Major of Editing and Publishing as Example.

\section{References}

[1] W. N. Dong, Research on Investigation of College Students' Professional Interests and Countermeasures, Journal of Dezhou University, 4 (2014) 104-108. (In Chinese)

[2] J. N. Cui, Construction of University WeChat Educational Platform Based on the View of Communication, Contemporary Education Science, 1 (2015) 39-41. (In Chinese)

[3] H. B. Huang, On the Application of WeChat Mobile Learning in the Course of Computer Application Foundation, Course Education Research, 7 (2015) 30. (In Chinese) 
[4] F. Z. Ding and L. Wu Occupational Dilemmas of Chinese Newspapermen in the Era of Socialized Media, News Journalists, 12 (2014) 3-9. (In Chinese)

[5] H. Y. Chen, Research on Mobile Assisted Teaching Practice Based on WeChat Accounts, Wireless Internet Technology, 7 (2014) 252-254. (In Chinese)

[6] W. E. Duan, Teaching Mode Construction of Deep Reporting Course On the Basis of WeChat Platform, Today's Massmedia, 8 (2015) 110-111. (In Chinese)

[7] Y. H. Kuang, Empirical Research on WeChat Public Platform Applied in Classroom Teaching, Journal of Inner Mongolia University of Finance and Economics, 7 (2015) 80-83. (In Chinese)

[8] J. N. Cui, Educational Platform Construction of University WeChat Based on the Perspective of Communication, Contemporary Education Science, 1 (2015) 39-44. (In Chinese)

[9] Q. Y. Wang, W. Z. Liu and Q. Chen, Enlightenment of the Application of WeChat in the Teaching of University Teachers, New Media Research, 4 (2015) 42-43. (In Chinese)

[10] Q. P. Zheng, Several thoughts on Cultivation of Professional Interests of University Students, Education and Teaching Forum, 6 (2014) 69-70. (In Chinese) 